Jurnal Administrasi Publik (Public Administration Journal)

Available online http://ojs.uma.ac.id/index.php/jap

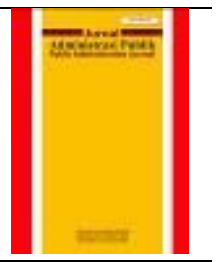

\title{
Implementation Analysis of the Village Council Function in Donowarih Village Administration, Malang Regency
}

\author{
Mariano Werenfridus, Zainul Rahman* \& Krishno Hadi \\ Government Science Study Program, Faculty of Social and Political Sciences, \\ University of Muhammadiyah Malang, Indonesia
}

Received: 02 July 2021; Reviewed: 02 July 2021; Accepted: 07 August 2021

* Corresponding Email:zainulrahman720@gmail.com

\begin{abstract}
Implementation of The Village Government (BPD) had a major role in achieving the performance of governance in the village. The effectiveness in carrying out the functions was determined by the synchronization related to the factors such as supervision, policy-making, and delivery of the people's aspirations. To answer this, the study was intended to analyze the implementation of the BPD function in Donowarih Village using qualitative approach-based software with tools of the analysis Nvivo. Obtained data collection through observation, interviews with relevant stakeholders, and the study of literature. The stages of analysis were conducted using Nvivo begins with an assessment of the three functions of BPD as embodied in Article 55 of Law No. 6 of 2014 about the Village. The results of this research showed that implementation of the functions of BPD in Donowarih Village was less effective caused by several factors, among others: the composition of human resources, facilities support activities of BPD, the differentiation of the major work of each member of the BPD, and the lack of benefits received by BPD members. Therefore, implementation of the function of BPD in Donowarih Village was less than the maximum due to such factors greatly affecting the performance of the glittering efforts of governance in the Donowarih Village.
\end{abstract}

Keywords: The village's consultative agency; The Function of The Village Government; Donowarih Village.

How to Cite: Werenfridus, M., Rahman, Z., \& Hadi, K., (2021), Implementation Analysis of the Village Council Function in the Implementation of Village Government. Jurnal Administrasi Publik (Public Administration Journal). 11 (2): 130 143 


\section{INTRODUCTION}

Regional autonomy provides great opportunities for community participation to be involved in development. However, in this case, the community is the object of development and gives more roles to the community as the subject of development. The main component of regional autonomy requires village government involvement to be more optimal (Firman, 2020). Villages have genuine autonomy because they are based on customary law. The autonomy in the village is different from the autonomy at the regional level. Regional autonomy is based on the transfer of authority from the central government, while villages have pure autonomy (Marisi, 2016).

Village government is the most important element in the administration of government at the local level. The existence of the village government was even recognized before Indonesia's independence and became the most important force in national development. (Purnamasari, 2019). In the administration of village government, there is a causal relationship with the birth of village autonomy which gives authority to the village to ensure development and development in the village (Zarkasi \& Dimasrizal, 2019).

Therefore, a good leadership pattern is required to support the implementation of governance at the village level. Institutionalized public participation in the village government structure allows participation in building and prospering village communities. In addition to involvement in non-formal institutions such as Non-Governmental Organizations (NGOs), they can also form community involvement through formal institutions, one of which is the establishment of the Village Consultative Body (BPD) (Putra \& Hapsari, 2020). The Village Consultative Body (BPD) is an embodiment of democracy at the village government level.
The BPD itself is also known as the village parliament; it is stated in Law Number 33 of 2004 concerning Regional Autonomy (Case et al., 2019). In the context of village government, the partnership between the BPD and the village government must prioritize the principle of checks and balances (Romli \& Nurlia, 2017). It means that the two institutions are not allowed to have a more dominant power. It was initiated to minimize the creation of weak and strong positions at the village government level.

BPD plays an important role as a means of control over the administration of village governance. The duties of the BPD are further confirmed in Permendagri No.110/2016, which discusses the duties of the Village Consultative Body (BPD). As an executive agency, the trias politica doctrine proclaimed by John Locke (1632-1704) and continued by Montesquieu (1689-1755) requires power limitation. Each power can be monitored and offset one another. Therefore, BPD is vital in administering government at the village level (Mardiyah et al., 2019). The structure in the village government is not much different from the structure in the central government. It can be seen from the division of roles as executive and legislative. The executive is run by the village head and village apparatus, while the legislature is in the hands of the BPD. BPD has a membership composition that is representative of the population based on the distribution of areas in the village (Firman, 2020). In Article 55 of Law Number 6 of 2014, the BPD has three fundamental functions, namely as an institution that with the village government discusses and agrees on draft village regulations, becomes a forum that accommodates and channels the aspirations of the village community and carries out the task of supervising the performance of the village head (Darmini). 2014, 2017). The BPD carries out this function and is a village partner in the 
administration of village governance (Dewi et al., 2020). BPD has a membership composition that is representative of the population based on the distribution of areas in the village (Firman, 2020). In Article 55 of Law Number 6 of 2014, the BPD has three fundamental functions, namely as an institution that with the village government discusses and agrees on draft village regulations, becomes a forum that accommodates and channels the aspirations of the village community and carries out the task of supervising the performance of the village head (Darmini). 2014, 2017). The BPD carries out this function and is a village partner in the administration of village governance (Dewi et al., 2020).

The partnership between the BPD and the village government in question fulfills the function of administering village government based on the applicable legislation. In carrying out its duties, the BPD takes on the role of full executor of the village community's sovereignty and represents the entire village community (Marisi, 2016). This partnership supports democratic life at the village level, which is strengthened through the regional autonomy law.

The existence of the BPD in carrying out its functions experienced several obstacles. This was concluded by various previous studies that described various factors causing the ineffectiveness of the role of the BPD in carrying out its function as a partner of the village government. Romli and Nurlia (2017) found that the role of the BPD became ineffective due to the incompetent quality of human resources, inadequately facilitated performance support facilities, and low income or allowances.

In addition, Putra \& Hapsari (2020) also found that the role of the BPD also could not be carried out properly due to the lack of understanding of BPD members about what duties and functions must be carried out properly making it difficult to adjust functions according to the law. Meanwhile, Marisi (2016) found the same thing that the passive involvement of BPD members was influenced by a lack of understanding of the duties and functions so that the administration of the village government was more borne by the village government. Based on existing research, the essence that makes BPD not play its role properly is due to the quality of human resources, inadequate supporting facilities, insufficient allowances and minimal understanding of their duties.

Purnamasari (2019) found that the shift in the function of the BPD resulted in the weak role of the BPD as a partner of the village government, which was supposed to carry out the functions of supervision, legislation and aspiration. Firman (2020) found several different things that the nonoptimal role of the BPD in the administration of village government was caused by the lack of main tasks that must be carried out. Firman sees that the tasks carried out by the BPD are only to accommodate aspirations and also form a village head election committee and establish village regulations.

While other findings have similarities with previous findings, Zarkasi \& Dimasrizal (2019), which discussed the pattern of cooperation between the village head and the BPD, found that the village head and the BPD did not have adequate knowledge in terms of village development. This is caused by the lack of technical guidance provided by the regional government to the BPD. Mardiyah et al. (2019) considered that the role of the BPD and the village government went well because of the coordination to carry out the BPD function properly.

Novianty (2019) discusses empirically juridically, finding that the BPD in Sungai Besar Village, Bunut Hulu District, Kapuas Hulu Regency has not been maximal in carrying out its duties and functions, one of which is related to accommodating and channeling 
community aspirations. Similarly, the study's results reviewed by Napir (2018) in Karyamukti Village, Gorontalo Regency, did not carry out the duties and functions of the BPD properly. Marande (2017) found that the less than optimal BPD in Tanamawau Village, West Tojo District, Tojo Una-Una Regency was caused by incompetent human resources. One of them is caused by the lack of guidance from the local government.

Based on the phenomena found in previous studies, the BPD in Donowarih Village, Karangploso District, Malang Regency, has not carried out its duties and functions properly by its functions as stated in Article 55 of Law Number 6 of 2014 concerning Villages. This was identified based on the lack of awareness of the BPD in Donowarih Village to be actively involved in carrying out their duties and functions.

In general, the problems found have similarities with previous studies. One of them is a misunderstanding about what to do. However, in terms of facilities in Donowarih Village, it has met the needs required to support BPD performance. The problem of awareness to carry out its duties and functions properly is a serious problem found in Donowarih Village.

Due to the lack of time, BPD members have to carry out their functions in the village government, such as holding meetings with the village government and village communities. The indication is the background of BPD members in Donowarih Village who have permanent jobs such as teaching staff, entrepreneurs, farming, etc. It has resulted in their duties and roles being limited by the main work of BPD members. Based on the study described earlier, the authors are interested in studying the factors that cause the less than the optimal role of the BPD in Donowarih Village in carrying out its duties and functions as an institution in the village government.

\section{RESEARCH METHOD}

This research utilized Nvivo 12 as qualitative data analysis software. This analysis dissected the discussion in several indicators, including implementation, deliberation, aspirations and accountability. They were prioritized Nvivo 12 to analyze qualitative content in facilitating and visualizing data according to the specified indicators. More specifically, specified the analysis of the role of the BPD in Donowarih Village based on the functions of regulation, supervision and aspirations.

This study was expected to contribute to the design of qualitative research. It explained the practice of implementing the BPD function in Donowarih Village, Karangploso District, Malang Regency, East Java Province. The subjects interviewed were Abdul Kohar as Head of BPD in Donowarih Village, Ary Widy Hartono, S. Kom., MH as Secretary of Donowarih Village and Muhammad Ihwan as representatives of community leaders. The purpose of this research was to review further the role and function of the BPD in Donowarih Village in actualizing its duties as a partner of the village government in the administration of village governance.

\section{RESULT AND DISCUSSION Synergy in Village Government}

Law Number 6 of 2014 concerning Villages Article 1 Paragraph (2) reads, "Village Administration is the administration of government affairs and the interests of the local community in the government system of the Unitary State of the Republic of Indonesia." Arsjad (2018) defines village government as the lowest system of administering government affairs. From a political perspective, village government is positioned as a powerful organization with certain authority within the country's government structure (Bron, nd). 
Anggalana (2020) explained that the position of village government in the government order is included in the category of autonomous government because it carries out all its household affairs independently. The implementation of village government involves several compositions so that in its implementation, it can run well. In this case, the element of the village head as the head of government in the village, village officials, and the Village Consultative Body (BPD) as a representation of the community are the main elements in administering government in the village (Nurwita, 2018).

The above elements carry out their duties and functions based on the applicable laws and regulations. In this case, the village head carries out his duties as the government, development, and community affairs organizer. Meanwhile, the BPD carries out functions, including accommodating and channeling community aspirations, carrying out supervisory duties on the performance of the village head, and participating in discussing and agreeing on draft village regulations with the village head (Antonius Erwandi, 2017). Based on the existing functions, the village government and the BPD also implement the trias political concept. In this case, the village head is the executive, and the BPD is the legislature (Anggalana, 2020). The BPD and the village government have a mutual relationship as partners with each other. The BPD carries out its role to embody the representation and aspirations of the community, while the village government carries out this in the administration of its government.

Can build synergy between village administration institutions if good communication is established (Dwinugraha, 2017). Therefore, systematic checks and balances must be carried optimally to support the creation of good governance at the local government level.

\section{Functions of the Village Consultative Body}

Law Number 6 of 2014 Article 55 concerning Villages outlines the three fundamental functions of the BPD. As a representative institution of the village community, the central role of the BPD is the main key to the implementation of good village governance. One of the functions of the BPD is to channel the aspirations of the village community. In carrying out its duties to articulate the interests of the village community, the law does not describe in detail what the BPD must carry out systems and patterns in each village (Rochmawanto, 2017).

This opinion is by the phenomenon that occurs so that the BPD in each village must be innovative to accommodate the aspirations of the village community. Can realize the form of implementation of the aspiration function through hamlet deliberations, village deliberations, and suggestions from community leaders and various other institutions. In addition to carrying out the aspiration function, the BPD and the village government jointly draft village regulations. This function has the priority to become the juridical basis for village government administrators (Hasanah \& Sururi, 2018).

The partnership between the BPD and the village government can be realized through a pattern of mutual respect and cooperation, for example, in the form of coordination related to making a policy. This condition allows the relationship between the village government and the BPD to run in a consultative and coordinating manner. Village regulations become the guideline for the BPD in controlling the implementation of village government functions. With village regulations as a source of law for administering village government, the BPD has an important role in enforcing village regulations, both in the form of village programs, as well as other forms of legal products that must carry out within a 
certain period (Setyaningrum \& Wisnaeni, 2019).

Supervision of the performance of the village head is one of the functions of the BPD. The concrete form of supervision of the performance of the village head is contained in Law Number 6 of 2014 Article 27 that the village head is obliged to provide final accountability to the BPD (Anggalana, 2020).

The form of accountability was one way to build public trust through the implementation of village programs. The BPD took on the role of a communicator to oversee the running of each program. The method taken was through a poll with community leaders to assess the village head's performance (Firman, 2020). Another alternative to monitoring the performance of the village head was to conduct evaluations on a weekly, monthly or annual basis. It is an effort to maintain the seriousness of the village government in carrying out its duties and functions as stipulated in the Act (Antonius Erwandi, 2017).

Next, this study described the three functions of the BPD; they were processed based on the results of joint interviews with relevant stakeholders. In addition, the interview results were processed using Nvivo 12 to find out how effective the role of the BPD in Donowarih Village was so that they were not able to find a common thread in the implementation of the BPD function. The focus of the analysis directed the object of discussion to underlie further the suitability between the indicators and the facts described (Anggraini, 2020). These indicators considered the dominance of answers based on the results of the interview. To ensure the accuracy of data processing, the three perspectives of the informants became a reference for analyzing and concluding how the implementation of this function had been going well or vice versa-assessed the analysis process based on the three main functions of the BPD.

\section{The Function of Discussing and Agreeing on the Draft Village Regulations with Village Head}

Analysis of this function was classified based on three main indicators to see the continuity of the function's implementation and the implications for the three main stakeholders, namely the village government, BPD, and community leaders. The BPD acted as a body that makes policies and carried out the task of supervising village policies so that BPD membership was a representation of the village community (Kurniawan, 2018). The relationship pattern between the BPD and the village government was the main thing because the implementation of both functions applies the principle of checks and balances (Deliana, 2020). BPD occupied a strategic position to implement democracy based on Pancasila so that in a working relationship, it partners with the village government (M. Abrar Nizhami, Safrul Rijali, 2018).

The village government and BPD have their philosophy in carrying out their duties, including prioritizing the common interests, mutual respect, having good intentions to remind each other and having an equal position as fellow partners (Pamuji et al., 2017). The function of the BPD, which was divided into three parts, cannot be separated from the role of the community as an object of policy. In this case, the communication system built must be more centered on the community because BPD becomes a symbol of democracy that represents the village community's needs, interests, and dreams (Gombo, 2018). The position of the BPD, when examined based on Law No. 32 of 2004, has a complex function. As an institution in the village, BPD has the task of holding village deliberations. The composition of the participants consists of 
the village head, community leaders, and group village officials.

In Donowarih Village, the composition of BPD members consists of various educational, occupational and background backgrounds of their respective interests. However, as a consequence of public representation, each BPD member must prioritize the public interest. Therefore, must be built the value of the integrity of each resource must be based on each individual's skills. The BPD's ability to observe its duties and functions must be based on performance-based professionalism (Pamuji et al., 2020). Therefore, implementing the BPD function becomes a fundamental demand because it works for the benefit of the community in general.

The indicators of communication patterns showed that the village government had a more dominant percentage of $55 \%$ compared to the BPD of $30 \%$. The domination of the village government was more dominant because it had a big role in holding discussions on the draft Perdes. Substantively, the role of communication must be dominated by the BPD because it was to build program synchronization and implement the specified functions (Lestari, 2020). However, the presentation revealed from the data showed the opposite fact. When viewed in terms of its function, the BPD must have a big responsibility to carry out intense communication with the village government regarding the procurement of activities in discussing and agreeing on existing regulations.

This inadequacy was certainly in sync with their involvement since the communication pattern in implementing this function was more focused on the role of the BPD and the village government. However, it had not maximized the involvement of the BPD in building intense communication with the village government. So that what happened was that the village government had more initiative to carry out activities that must be the duties and functions of the BPD. Conceptually, the logical consequence of the role of the BPD requires structured supervision to support the implementation of this function. In line with this argument, Article 55 emphasized that the supervision carried out by the BPD on the performance of the village government had a serious impact on the interests of the community (Nurjaman, 2018).

In addition, one of the important indicators regarding the implementation of these duties and functions is the political factor. The processed data showed that the village government had a dominance of $54.55 \%$ compared to the BPD, which is only $27.27 \%$. In building political dominance, more emphasized the task of the BPD to accommodate the interests of the community and its supervision of the village government (Susanto, 2019). Therefore the domination of its implementation was not taken over by the village government. Still, the BPD must further optimize the political role that bridges the community and the village's government side. Political domination in this function must be more controlled by the BPD because to produce a regulation by the community's will, the BPD was able to aspire to it in the form of a directed regulation.

Meanwhile, based on these results, the village government was more involved in politics because the village government better understood what must regulate things in regulations. In this study, the political role of the community was still very minimal because the specificity of this function was only specific to the village government and BPD. Therefore, the involvement of the community was only $18.18 \%$.

Regarding regulatory indicators, the role of the village government was still quite dominant with a percentage of $75 \%$ compared to the BPD, which was only $25 \%$. It was due to BPD's human resources, who 
were less qualified in understanding their duties. Therefore, village governments tended to be more dominant because they understood the legislative process. The synthesis of these various data was inversely proportional to the role of the BPD in implementing its legislative function and making policies or regulations gave special legislation functions to the competent institutions in this regard. Within the scope of village government, it was the function of the BPD that theoretically took over this authority. Policies with minimal BPD domination will only impact people's lives (Komala, 2017).

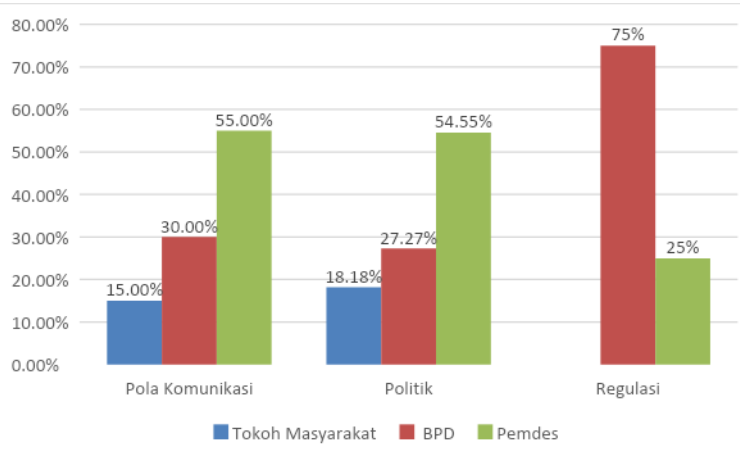

Figure 1. Indicators in Assessing Legislative Function

\section{The function of Accommodating and Distributing Village Community Aspirations}

BPD, in carrying out the aspiration function, its main task was to explore, process, and channel the aspirations of the community in the form of ideas, suggestions, and criticisms so that they were able to be used as benchmarks in decision making (Alexsander Palen, 2020). Legally regulated membership of the BPD in Donowarih Village based on the decision of the Malang Regent Number: 188.45/296/KEP/35.07.013/2020

concerning the Ratification of the Dismissal and Appointment of Interim Substitute Village Consultative Body Members in Donowarih Village, Karangploso District, for the 2019-2025 term of office. The number of BPD members based on the decree is nine people. In administrative management, the educational background of BPD members was seven people with a bachelor's degree level of education, and two others are high school graduates.

The role of education in BPD membership became an important part of determining the quality and integrity of performance implementation. The relationship between the level of education and the impact on performance was closely related to the effectiveness, vision, and mission of the BPD as the organization's face. As part of community representation, performance improvement is manifested in the organization's goals, objectives, mission, and vision (Aprila, 2020). The implications of the level of education were directly proportional to the implementation of the BPD function. When viewed from the educational standards of BPD members in Donowarih Village, recorded that bachelor's degree graduates dominated the level of education. In contrast, some other BPD members were only high school graduates.

The implementation of this function was able to run well when viewed based on several factors. In terms of management, the village government took over the dominant role by $50 \%$, while the BPD only amounted to $37.50 \%$. This inequality in roles was seen from the lack of initiative in implementing functions to accommodate and channel the aspirations of the village community. This was able to be caused by limited experience and skills in managing roles. The minimal involvement of BPD members resulted in more community complaints being submitted directly to the village government. The lack of these initiatives was in line with the role of legislation which was less dominant, so that, on the other hand, it became a particular problem. Lack of understanding in terms of legal drafting as well as managerial was the main cause of the lack 
of dominance of the role of BPD (Nelson et al., 2019)

The role of the community, in this case, was only $12.50 \%$ because the community is a third party in terms of managerial administration of government. Therefore, whether or not the channeling of aspirations by the community was effective is determined by the autonomy of the duties and functions of the village government and the BPD alone. On the other hand, community participation must be an important component that can be used as an argument for BPD members to form village government policies and programs (Anjasmara, 2018). However, the lack of involvement of the BPD in allocating community aspirations was still very minimal, so that the community tends to submit directly to the village government. This shows that the inequality of roles in accommodating the community's needs in general in all respects was more dominated by the village government.

In addition, infrastructure was important in carrying out the duties and functions of the BPD. In 2020, the budget for implementing siltap spending, allowances, and BPD operations were only $\mathrm{Rp}$ from January to May 2020. 12,250,000, and from June to December 2020, it is Rp. 17,150,000. This budget constraint caused the lack of supporting infrastructure such as stationery, allowances for picket implementers (external BPD), etc. The implementation budget in carrying out tasks had contained operational funds other than salaries and allowances in the RAPBDes (Mutia, 2018). So it was expected to be more optimal. However, this is different from the budgeting pattern in Donowarih Village, which in percentage terms was less than optimal, which had a significant impact on improving the performance of the BPD.

The BPD had a minimal presentation of $15 \%$, so that it affected the performance of the BPD in terms of attendance at the BPD office. This minimal involvement had resulted in the tendency of community aspirations not being fully accommodated so that the village government took a more dominant role, which was $70 \%$. The budget provided had a systemic impact on the ineffectiveness of implementing BPD tasks. In addition, it affected performance orientation, even though conceptually performance was divided into two things, namely employee performance per individual and organizational performance (Djabar, 2018). The two performances had a very close relationship because they affected the achievement of BPD goals, which could not separate from the important role of human resources, which in budgetary terms had a dominant impact in the provision of supporting infrastructure.

Another factor that also impacted the implementation of this function was the lack of time for deliberation both within the internal BPD and between the community and the BPD. This limitation was caused by the background of BPD members who had core jobs such as teaching staff, farmers, entrepreneurs, etc. This has led to a dichotomy of focus between duties as members of the BPD and carrying out their core work. The lack of time-intensity to meet with fellow BPD members accumulated by $33.33 \%$. The intensity of coordination among members determined the foundation of BPD work. A good level of coordination in the implementation of BPD functions was not able to be illustrated by the products produced, for example, articulating the community's aspirations.

Massive involvement determines the direction of movement of the presence of BPD members. However, several previous studies had also stated that the limited performance of BPD was dominated by the lack of time together. This was able to be traced through the diversification of the work background of each BPD member (Putra Rizki Rahadianto, Silviana Ana, 2017). So that in bridging this function, the village government was more dominant to jointly with the BPD conduct aspirational 
screening in each hamlet. The village government dominates with a percentage of $60 \%$.

Meanwhile, the BPD itself performs minimal functions because the time for consolidation was very limited and is even carried out at night to become less effective. Besides that, the head of the BPD concerned lacks the initiative to provide the understanding obtained to other members. On the other hand, the lack of technical implementation that did not provide sustainably affects the performance of the BPD. The central role of the BPD chairman, in this case, was to be a promoter who moves fellow BPD members. The stated presence of BPD members in building the organization's face through their involvement in the coordination process (Kembuan et al., 2017). In its implementation in Donowarih Village, the lack of dominance of the BPD chairman greatly affects the work of other BPD members. On the other hand, the varied work backgrounds of BPD members could be used as a factor causing the lack of massive BPD performance in Donowarih Village.

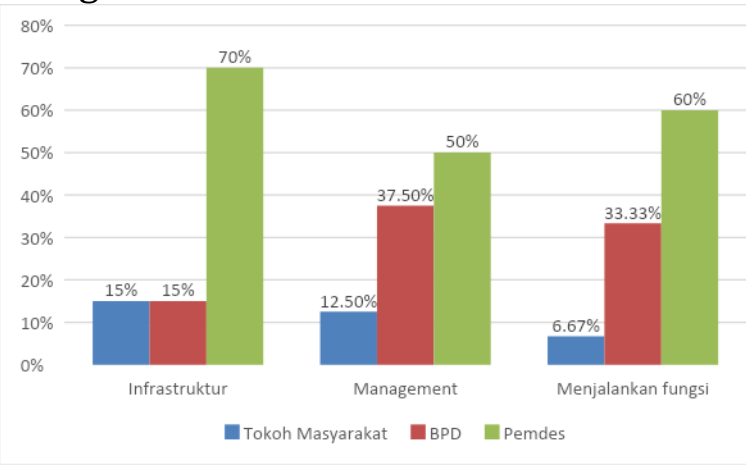

Figure 2. Aspiration Function Indicators

\section{Village Head Performance Monitoring Function}

The supervisory function was one of the important elements of the three BPD functions. Conceptually, required BPD as a supervisory body to carry out its functions in a professional, transparent, independent and participatory manner because the recruitment system involves the community in general (Astuti, 2017). Therefore, in achieving an effective and optimal monitoring system, the BPD must implement certain criteria, including objectivity, in supervising so that the accuracy of the evidence and facts are synchronized. Expected The quality of supervision as a village legislature to avoid corruption, collusion and nepotism at the village level (Elpita Heriyanti, 2017). Therefore, the consequences of the supervisory function were the backbone of the optimal performance of the village government.

The implementation of BPD performance in the supervision system was an important priority to ensure that village administration could run optimally (Awaluddin \& Hendra, 2018). In this research, the relationship between the village government as the executive and the BPD as the village legislature had a reciprocal relationship. The principle of checks and balances was able to be realized through a structured accountability report. In Donowarih Village, the implementation of the accountability report was not carried out in an orderly and consistent manner due to the lack of initiative and involvement of BPD members. This was seen from the performance of $45 \%$ lower than the village government with a percentage of $50 \%$. The dominant involvement of the village government was a benchmark due to the limited number of BPD members who had very few evaluation meetings.

The impact of the result led to the performance of other BPDs in terms of supervision of the village apparatus. The recorded data had shown that the role of BPD was only $30 \%$. This phenomenon was seen from the quality of BPD human resources who have closeness both emotionally and based on certain interests so that the implementation of supervision was not optimal. Meanwhile, in terms of village government, it was more dominant 
with a percentage of $50 \%$. In this context, the village government preferred to implement the principle of checks and balances, which was realized through the initiative to build closeness by holding meetings based on the initiation by the village government.

Supervision of village government programs was still not optimal because it is influenced by several factors: the minimal allowance for BPD members and the pattern of receipts per six months. The range received per month varies, with a nominal value of IDR 200,000 to IDR 350,000 per month per person. Did not properly monitor, as a result, the supervision system for village government programs such as village funds, infrastructure development, and the Covid19 task force formation. The minimal involvement of the BPD is recorded at 35\%, while the village government was always more dominant with a percentage of $45 \%$. Supervision of the implementation of village government programs is constrained by internal factors such as the lack of coordination between fellow BPD members, resulting in the village government working "alone."

An overview of the explanation above showed that the implementation of the function in supervising the performance of the village head is less than optimal as measured by various factors. In addition to what had been described, the most important thing in supervision is monitoring and evaluation. Monitoring and evaluation were implicitly related to the village government administration's planning, implementation, and reporting (Dera Pratama Puja Lestari, Rahmi Hayati, 2019). These aspects were preventive measures so that in carrying out the duties and functions of the village government, there were no deviations and must be ensured by applicable principles, running according to what was planned and when found problems. They were able to produce solutions (Handayani, 2021).
The BPD in Donowarih Village, in carrying out its supervisory function of the village government, had not carried out massive and consistent monitoring and evaluation. The lack of dominance showed it to carry out supervision so that in terms of presentation based on existing data, the village government was still the dominant actor. The BPD, as an institution that embodies democracy, should carry out its supervisory function over the village government and collaborate with the village head to be able to embrace aspirations and channel ideas and ideas from the community (Urrahmi et al., 2020). The existence of BPD in Donowarih Village must undergo administrative and managerial reform to produce a performance that has a positive effect on the community from all aspects.

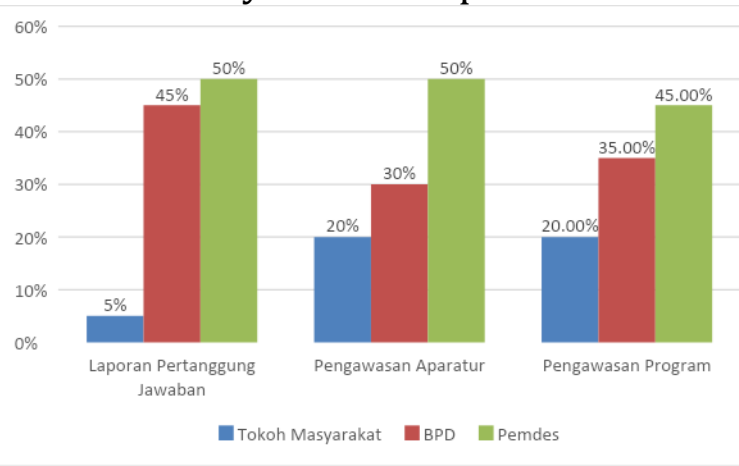

Figure 3. Monitoring Function Indicators

\section{CONCLUSION}

Analysis of the implementation of the BPD function in Donowarih Village encountered several obstacles caused by several factors. The existence of these obstacles affected the performance of the BPD in fulfilling its duties and functions based on the applicable law. These factors included: First, the composition of human resources for BPD members in Donowarih Village was dominated by undergraduate graduates. It provided an opportunity to be able to produce good surveillance products. However, the facts on the ground had shown that the level of dominance of involvement between the BPD and the village government was more likely to be 
spearheaded by the village government due to a weak level of awareness or initiative. Second, in terms of facilities to support the implementation of BPD functions, it was found that there were still some shortcomings, including the availability of computer equipment, procurement of picket officers, and also insufficient funding to support the implementation of daily activities. In addition to technical facilities, the lack of guidance and technical provision to all BPD members also affected the relevant agencies' performance on an ongoing basis. Third, the involvement of BPD members in carrying out their duties and functions was experiencing problems because all BPD members had basic jobs such as farmers, teaching staff, entrepreneurs, and others. It affected performance, which impacts the less massive intensity of meetings, both about evaluative and technical tasks. Fourth, the next factor was the problem of allowances constrained by the process and the nominal obtained. In this study, not received the system of providing allowances every month, but quarterly or even semester. The nominal received was only around $\mathrm{Rp}$. 200,000 to Rp. 350,000 . These obstacles were the common thread of the analysis of the implementation of the duties and functions of the BPD in Donowarih Village.

\section{REFERENCES}

Alexsander Palen, T. (2020). Pelaksanaan Fungsi Badan Permusyawaratan Desa (BPD) dalam Menyalurkan Aspirasi Pembuatan PERDES (Studi Pembuatan Perdes Tentang BUMDES di Desa Bleberan Kecamatan Playen Kabupaten Gunung Kidul Provinsi Daerah Istimewa Yogyakarta). Jurnal Political Science.

Anggalana. (2020). Sinergitas Pemerintahan Desa Dalam Pembentukan Peraturan Desa.Jurnal Ilmu Hukum, 15 nomor 1(9), 1-119.

Anggraini, Y. (2020). Analisis Fungsi Badan Permusyawaratan Desa Dalam Menampung Dan Menyalurkan Aspirasi Masyarakat Di Desa Pulau Kumpai Kecamatan Pangean Kabupaten Kuantan Singingi. Jurnal Fakultas Ilmu Sosial.

Anjasmara, S.S. (2018). Pelaksanaan Fungsi Badan Permusy Aw Arat An Desa Dalam Pembentukan
Pera Turan Desa Di Desa T Anjungsari Kecamatan Gunungt Anjung Kabupaten Tasikmalaya. Res Publica, 2(3), 317-329.

Aprila, W. (2020). Analisis Pelaksanaan Fungsi Badan Permusyawaratan Desa (BPD) Dalam Penyelenggaraan Pemerintahan Sangkulirang Kabupaten. Analisis Pelaksanaan Fungsi Badan Permusyawaratan Desa (BPD) Dalam Penyelenggaraan Pemerintahan Sangkulirang Kabupaten, 8(2), 355-368.

Arsjad, M. F. (2018). Peranan Aparat Desa dalam Pelaksanaan Administrasi Pemerintahan Desa di Desa Karyamukti Kecamatan Mootilango Kabupaten Gorontalo. Gorontalo Journal of Public Administration Studies, 1(1), 16. https://doi.org/10.32662/gjpads.v1i1.176

Astuti, P. F. (2017). Pelaksanaan Fungsi Pengawasan Bumdes Tirta Mandiri Desa Ponggok Kecamatan Polanharjo Kabupaten Klaten. Journal of Politic and Government Studies, 6(2).

Awaluddin, \& Hendra. (2018). Fungsi Manajemen Dalam Pengadaan Infrastruktur Pertanian Masyarakat Di Desa Watatu Kecamatan Banawa Selatan Kabupaten Donggala. Jurnal Fakultas Ilmu Sosial Dan Ilmu Politik Universitas Tadulako Indonesia, 2(1), 1-12.

Darmini. (2017). Peran Badan Permusyawaratan Desa di Dalam Pembangunan Desa dan Pengawasan Keuangan Desa Darmini Roza * dan Laurensius Arliman S ** A . Latar Belakang Pembentuk Undang-Undang Dasar Negara Republik Indonesia Tahun 1945 (UUD 1945) mempertahankan pemerintah. Ilmu Hukum PJIH UNPAD, 4(26), 606-624.

Deliana, O. R. (2020). Pelaksanaan Fungsi Legislasi Badan Permusyawaratan Desa (BPD) dalam Kerangka Otonomi Desa (Studi Di Desa Girimoyo Kecamatan Karangploso Kabupaten Malang). Doctoral Dissertation, Universitas Islam Malang.

Erwandi, A., (2017). Peranan Badan Permusyawaratan Desa (BPD) dalam Menampung Dan Menyalurkan Aspirasi Untuk Melestarikan Budaya Masyarakat Di Desa Solam Raya Kecamatan Sungai Tebelian Kabupaten Sintang. Jurnal Ilmu Hukum, 4(2), 93-106.

Lestari, D. P. P., Hayati, R., \& Suryani, L. (2019). Fungsi Badan Permusyawaratan Desa Dalam Mengawasi Kinerja Kepala Desa Di Desa Kapar Kecamatan Murung Pudak Kabupaten Tabalong. JAPB, 2(2), 509-522.

Dewi, I., Sumarni, T., \& Indra, I. (2020). Peran Badan Permusyawaratan Desa (BPD) terhadap Pemerintahan Desa Studi Kasus Desa Pambang Pesisir Kecamatan Bantan. Jurnal Yustisiabel, 4(2), 118. https://doi.org/10.32529/yustisiabel.v4i2.508 
Djabar, K. M. A. B. D. (2018). Fungsi Legislasi Di Kecamatan Talatako Kabupaten Tojo Una-Una. $E$ Jurnal Katalogis, 6(3), 77-87.

Dwinugraha, A. P. (2017). Sinergitas Aktor Kepentingan Dalam Penyelenggaraan Pemerintahan Desa (Studi pada Desa Urek-Urek Kecamatan Gondanglegi Kabupaten Malang). Publisia: Jurnal Ilmu Administrasi Publik, 2(1), 1-7. https://doi.org/10.26905/piiap.v2i1.1421

Heriyanti, E., \& SD, Z. R. (2017). Fungsi Badan Permusyawaratan Desa (BPD) dalam Mengawasi Kinerja Kepala Desa di Desa Kuok Kecamatan Kuok Kabupaten Kampar (Doctoral dissertation, Riau University).

Firman, F. (2020). Peranan Badan Permusyawaratan Desa dalam Penyelenggaraan Pemerintahan di Desa. Al-Ishlah : Jurnal Ilmiah Hukum, 23(1), 3952. https://doi.org/10.33096/aijih.v23i1.35

Gombo, H. (2018). Kedudukan Badan Permusyawaratan (BPD) Dalam Penyelenggaraan Pemerintahan Desa Tagipaga Distrik Koragi Kabupaten Jayawijaya. Lex Et Societatis, 6(3), 51-60.

Handayani, Y. (2021). Peran BPD (Badan Permusyawaratan Desa) dalam Menampung dan Menyalurkan Aspirasi Masyarakat pada Proses Pelaksanaan Pembangunan. Syntax Literate; Jurnal Ilmiah Indonesia, 6(1), 478485.

Hasanah, B., \& Sururi, A. (2018). Peningkatan Kapasitas Aparatur Pemerintahan Desa dan Masyarakat Melalui Pelatihan Administrasi Pemerintahan di Desa Sukamenak Kecamatan Cikeusal Kabupaten Serang. Wikrama Parahita: Jurnal Pengabdian Masyarakat, 2(2), 68. https://doi.org/10.30656/jpmwp.v2i2.606

Kembuan, K. T., Lumolos, J., \& Sumampow, I. (2017). Fungsi Badan Permusyawaratan Desa Dalam Perencanaan Pembangunan Di Desa Kopiwangker Kecamatan Langowan Barat Kabupaten Minahasa. Jurnal Eksekutif, 1(1), 111.

Komala, R. (2017). Pelaksanaan Fungsi Legislasi Badan Permusyawaratan Desa Pandansari Kecamatan Ajibarang Kabupaten Banyumas. Doctoral Dissertation, Universitas Jenderal Soedirman.

Kurniawan, M. N. R. (2018). Pelaksanaan Fungsi Badan Permusyawaratan Desa (BPD) Di Desa Binabaru Kecamatan Kampar Kiri Tengah Kabupaten Kampar. Jurnal Online FISIP, Vol. 5 No.

Lestari, F.A. (2020). Pelaksanaan Fungsi Badan Permusyawaratan Desa (BPD) Berdasarkan Peraturan Menteri Dalam Negeri Nomor 110 Tahun 2016 Di Desa Pulau Rambai Kecamatan Kampa. Doctoral Dissertation, Universitas Islam Negeri Sultan Syarif Kasim Riau.

M. Abrar Nizhami, Safrul Rijali, S. A. (2018). Efektivitas Fungsi Badan Permusyawaratan Desa Dalam
Menunjang Penyelenggaraan Pemerintahan Desa Di Desa Tanta Kecamatan Tanta Kabupaten Tabalong. Jurnal Administrasi Publik Dan Administrasi Bisnis, 1(1).

Marande, Y. (2020). Kualitas Pelayanan Publik di Kantor Kelurahan Gebangrejo Kecamatan Poso Kota Kabupaten Poso. Jurnal Ilmiah Administratie, 8(1), 33-39.

Mardiyah, S. A., Ilmu, M., \& Universitas, P. (2019). Imported from https://journal.unhas.ac.id/index.php/governm ent/article/view/8049/4293. 12. https://journal.unhas.ac.id/index.php/governm ent/article/view/8049/4293

Marisi, A. (2016). Fungsi Badan Permusyawaratan Desa (BPD) dalam Penyelenggaraan Pemerintahan Desa Di Desa Kelinjau Ilir Kecamatan Muara Ancalong Kabupaten Kutai Timur, eJournal Ilmu Pemerintahan, 4 (3): 981-994.

Maslikan, A.J. (2020). Fungsi Badan Permusyawaratan Desa (BPD) Dalam Penyelenggaraan Pemerintahan Desa (Studi Di Desa Krandon Kecamatan Kota Kabupaten Kudus). Jurnal Keadilan Hukum, 1(2), 6-12.

Mutia, F. (2018). Implementation of Supervision Function Of Village Agency In Management of Village Government (Village Study Sinaka Kecamatan Pagai Selatan). Jurnal Jips, 2(3), 5159.

Napir, S. (2018). Analisis Penguatan Fungsi Badan Permusyawaratan Desa (BPD) di Desa Karyamukti Kabupaten Gorontalo. Gorontalo Journal of Government and Political Studies, 1(1), 40. https://doi.org/10.32662/gjgops.v1i1.173

Nelson, N., Samudin, M. T., \& Nurmiati, N. (2019). Pelaksanaan Fungsi Badan Permusyawaratan Desa Di Desa Watubula Kecamatan Dolo Kabupaten Sigi. Jurnal Kolaboratif Sains, 1(1).1445-1452.

Yuliananingsih, Y., Novianty, F., \& Jumiati, J. (2019). Fungsi Badan Permusyawaratan Desa (BPD) Dalam Mengawasi Kinerja Kepala Desa Di Desa Sungai Besar Kecamatan Bunut Hulu Kabupaten Kapuas Hulu.Sosial Horizon: Jurnal Pendidikan Sosial, 6(1), 123-134.

Nurjaman, A. (2018). Pelaksanaan fungsi BPD dalam melakukan pengawasan kinerja kepala Desa di Desa Sadang Kecamatan Sucinaraja Kabupaten Garut dihubungkan dengan UU No. 6 tahun 2014 tentang Desa. Doctoral Dissertation, UIN Sunan Gunung Djati Bandung.

Nurwita, I. (2018). Desentralisasi Badan Pemberdayaan Masyarakat Dan Pemerintah Desa Dalam Mendukung Tata Pemerintahan Daerah Kabupaten Gorontalo. Gorontalo Law Review, 1(2), 41-48.

Pamuji, K., Ardhanariswari, R., \& Asyik, N. (2020). Peningkatan Kapasitas BPD sebagai Mitra 
Pemerintah Desa dalam Pengembangan Potensi Pariwisata Desa di Kecamatan Baturaden. Borobudur Journal on Legal Services, 1(2), 6581. https://doi.org/10.31603/bjls.v1i2.3992

Pamuji, K., Nasihuddin, A. A., Ardhanariswari, R., \& Supriyanto, S. (2017). Pengembangan Model Peran Badan Permusyawaratan Desa (BPD) Dalam Penyelenggaraan Pemerintahan Desa Di Desa Banjarpanepen Kecamatan Sumpiuh Kabupaten Banyumas. Prosiding, 7(1).14181428.

Purnamasari, G. C. (2019). Pergeseran Fungsi Dan Kedudukan Badan Permusyawaratan Desa Menurut Undang-Undang Nomor 6 Tahun 2014 Tentang Desa (Studi Bpd Desa Kunjang). Refleksi Hukum: Jurnal Ilmu Hukum, 3(2), 161-174. https://doi.org/10.24246/jrh.2019.v3.i2.p161174

Putra, M. E., \& Hapsari, A. N. S. (2020). Peran Badan Permusyawaratan Desa dalam Pengelolaan Aset Desa. Jurnal Akuntansi Maranatha, 12(1), 109122. https://doi.org/10.28932/jam.v12i1.2009

Rahadianto, P.R., \&Ana, T.S., (2017). Pelaksanaan Fungsi Badan Permusyawaratan Desa Dalam Mewujudkan Demokrasi Desa Di Desa Paulan Kecamatan Colomadu Kabupaten Karanganyar. Diponegoro Law Journal, 5(3), 1-13.

Rochmawanto, M. (2017). Kedudukan Badan Permusyawaratan Desa Dalam Pemerintahan
Desa (Studi di Desa Deket Wetan Kecamatan Deket Kabupaten Lamongan). Jurnal Independent, 5(1), 33. https://doi.org/10.30736/ji.v5i1.64

Romli, O., \& Nurlia, E. (2017). Lemahnya Badan Permusyawaratan Desa (BPD) Dalam Melaksanakan Fungsi Pemerintahan Desa (Studi Desa Tegalwangi Kecamatan Menes Kabupaten Pandeglang). CosmoGov, 3(1), 36. https://doi.org/10.24198/cosmogov.v3i1.1263 5

Setyaningrum, C. A., \& Wisnaeni, F. (2019). Pelaksanaan Fungsi Badan Permusyawaratan Desa Terhadap Penyelenggaraan Pemerintahan Desa. Jurnal Pembangunan Hukum Indonesia, 1(2), 158-170. https://doi.org/10.14710/jphi.v1i2.158-170

Susanto, H. (2019). Evaluasi Pelaksanaan Fungsi Badan Permusyawaratan Desa (BPD) di Desa Palas Kecamatan Pangalan Kuras Kabupaten Pelalawan. Doctoral Dissertation, Universitas Islam Riau.

Urrahmi, M., \& Putri, N. E. (2020). Manajemen Konflik Pengadaan Tanah Pembangunan Jalan Tol Padang-Sicincin. Jurnal Mahasiswa Ilmu Administrasi Publik, 2(2), 9-17.

Zarkasi, A., \& Dimasrizal, D. (2019). Pola kerjasama kepala desa dengan badan permusyawaratan desa dalam pembangunan desa. Unri Conference Series: Community Engagement, 1, 652-657. 